\title{
Synthesis of $\boldsymbol{C}_{2}$-Symmetric Dimeric $\operatorname{Re}(\mathrm{I})$ Peptide Complexes
}

\author{
Richard S. Herrick ${ }^{[a]}$, Christopher J. Ziegler ${ }^{[b]}$, Kathryn L. Kennedy ${ }^{[a]}$, Calvin Luu ${ }^{[a]}$, and \\ James T. Engle ${ }^{[b]}$
}

Richard S. Herrick: rherrick@holycross.edu

[a]Department of Chemistry, College of the Holy Cross, Worcester, MA 01610, Fax: $(+1)$

508-793-3530

[b]Department of Chemistry, University of Akron, Akron, OH 44325

\begin{abstract}
The reactions of $\left[\operatorname{Re}(\mathrm{CO})_{3}\left(\mathrm{H}_{2} \mathrm{O}\right)_{3}\right] \mathrm{Br}$ or $\operatorname{Re}(\mathrm{CO})_{5} \mathrm{Cl}$ with two peptides, glycylglycine or glycylalanine, were investigated. Each reaction produced a unique, well-defined product. Structural elucidation showed the formation of chiral compounds with the formula $\left[\operatorname{Re}(\mathrm{CO})_{3}(\mathrm{Gly}-\right.$ $\mathrm{Xxx}-\mathrm{O})]_{2}, \mathrm{Xxx}=$ Gly $\mathbf{1}$, Ala 2.

Each dimer displays $C_{2}$-symmetry and a nearly rectangular shape. The ligands are bound via the amine and amide carbonyl at a rhenium center and via the pendant carboxylate to the adjacent rhenium center. Both products are fully characterized, via X-ray structure elucidation.
\end{abstract}

\section{Keywords}

Carbonyl ligands; Crystal structures; Dipeptides; Rhenium

\section{Introduction}

There is newfound interest in the organometallic chemistry of rhenium as reports of biological applications emerge. ${ }^{[1-2]}$ The first biological use for organometallic rhenium compounds was as a cold analog for ${ }^{99 \mathrm{~m}} \mathrm{Tc}$. Technetium- $99 \mathrm{~m}$ is the most commonly used radionuclide in nuclear medicine, ${ }^{[3]}$ but technetium has no stable nuclides. Development of the Isolink ${ }^{\circledR}$ kit provides clinical access to ${ }^{99 \mathrm{~m}} \mathrm{Tc}(\mathrm{CO})_{3} \mathrm{~L}_{3}$ compounds, [4] which has widened the search for radiopharmaceutical candidates and increased interest in $\operatorname{Re}(\mathrm{CO})_{3} \mathrm{~L}_{3}$ model compounds. More recently, as rhenium-188 (half-life of 17 hours with $\beta^{-}=2.1 \mathrm{MeV}$ ) becomes available carrier-free, and a clinically relevant formulation becomes available for the ${ }^{188} \operatorname{Re}(\mathrm{CO})_{3}{ }^{+}$core, ${ }^{[5-7]}$ there is interest in theranostic treatments, where a matched pair of ${ }^{99 \mathrm{~m}} \mathrm{Tc}$ and ${ }^{188} \mathrm{Re}$ compounds would target the same location for diagnostic and therapeutic uses, respectively. ${ }^{[8]}$ Supplementing these research ideas, $\mathrm{d}^{6}$ rhenium compounds with fluorescent ligands tested in vivo provide yet another application for these compounds. ${ }^{[9-11]}$

We have previously published studies on the possible biological relevance of the $\mathrm{d}^{6}$ chemistry of rhenium. These include crystal structures of the triaqua cation, ${ }^{[12]}$ and new compounds with monodentate, ${ }^{[13]}$ bidentate ligands ${ }^{[14-16]}$ or tridentate ligands. ${ }^{[1,17-19]}$ In addition to creating new molecules and developing aqueous methods of preparing previously reported compounds, we reported on the use of these compounds as models of metalessential radiopharmaceuticals. ${ }^{[20]}$ We have also prepared amino acid conjugates via Schiff 
base formation of diimines. ${ }^{[15,21-22]}$ Recently we have looked at reactions of the dipeptide His-His-OH to study the possibilities of using histidine peptide conjugates as the chelating portion of a target-specific radiopharmaceutical. The resulting highly stable compound had a surprising structure with two $\operatorname{Re}(\mathrm{CO})_{3}{ }^{+}$units bound very tightly to the dipeptide. The zwitterionic molecule is highlighted by a deprotonated amide nitrogen. This causes the deprotonated peptide bond unit to span the two metal centers with the carboxamido-nitrogen binding one rhenium center and the adjoining carbonyl oxygen binding the second rhenium center (Scheme 1). ${ }^{[21]}$ As proteins are biological molecules that rhenium prodrugs will encounter in plasma, it is vital to have a detailed understanding of protein and peptidereactivity with $\mathrm{Re}(\mathrm{CO})_{3}\left(\mathrm{H}_{2} \mathrm{O}\right)_{3}{ }^{+}$. For these reasons, we are extending our study of reactions of biological molecules with $\operatorname{Re}(\mathrm{CO})_{3}+\cdot[23-25]$

Herein we report an extension of our investigations into the reactions of peptides with $\operatorname{Re}(\mathrm{CO})_{3}$ precursor molecules. In contrast to the linear complex with a $2: 1$ $\mathrm{Re}(\mathrm{CO})_{3}$ :dipeptide stoichiometry formed by reaction with His-His-OH (Scheme 1), the reactions of the dipeptides Gly-Gly-OH and Gly-L-Ala-OH with $\mathrm{Re}(\mathrm{CO})_{3}\left(\mathrm{H}_{2} \mathrm{O}\right)_{3}{ }^{+}$produced a cyclic dimeric product, $\left[\operatorname{Re}(\mathrm{CO})_{3}(\mathrm{Gly}-\mathrm{Xxx}-\mathrm{O})\right]_{2}, \mathrm{Xxx}=$ Gly $\mathbf{1}$, Ala 2 (Scheme 2$)$. We present the preparation, spectroscopic properties, and structural elucidation of these new compounds and discuss their striking geometries.

\section{Results and Discussion}

Scheme 2 shows the reaction for the syntheses of compounds $\mathbf{1}$ and $\mathbf{2}$. They were prepared from $\mathrm{Re}(\mathrm{CO})_{5} \mathrm{Cl}$ or $\left[\operatorname{Re}(\mathrm{CO})_{3}\left(\mathrm{H}_{2} \mathrm{O}\right)_{3}\right] \mathrm{Br}$ in either mixed methanol:water or aqueous solution. Yields were modest but repeatable, and clean, white microcrystalline solids resulted for both peptides.

Crystals for structural elucidation were grown by vapor diffusion of water (1) or $\mathrm{CH}_{2} \mathrm{Cl}_{2}$ (2) into DMSO. Their structures, shown in Figures 1 and 2 respectively, ${ }^{[26]}$ reveal that each compound is a $C_{2}$-symmetric cyclic dimer. The amine terminus and amide carbonyl oxygen of one dipeptide binds in a bidentate manner to the first rhenium center while the terminal carboxylate oxygen binds the sixth coordination site of the second rhenium center. The other dipeptide binds in an identical fashion, but in the opposite direction to connect the two metals. Each rhenium ion in the two compounds has a nearly octahedral geometry and displays facially arranged carbonyls. All bond lengths and angles are within the normal range typically observed for rhenium tricarbonyl compounds.

The structures and stoichiometries of $\mathbf{1}$ and $\mathbf{2}$ are distinctly different from the dimer resulting from reaction of $\mathrm{Re}(\mathrm{CO})_{3}\left(\mathrm{H}_{2} \mathrm{O}\right)_{3}{ }^{+}$with His-His-OH (Scheme 1); this difference is due to Gly-Gly-OH and Gly-Ala-OH both lacking side groups with donor atoms. Instead, the structures of $\mathbf{1}$ and $\mathbf{2}$ are reminiscent of the amino acid conjugates $\left[\operatorname{Re}(\mathrm{CO})_{3}(\text { pyca-Xxx-O) }]_{2}\right.$ $(\mathrm{Xxx}=\mathrm{Gly}, \mathrm{Ala}$; pyca $=$ pyridine-2-carbaldehyde imine $)$ and share $C_{2}$-symmetry. ${ }^{[22]}$ Like the $\left[\operatorname{Re}(\mathrm{CO})_{3}(\text { pyca-Xxx-O) }]_{2}\right.$ compounds, $\mathbf{1}$ and $\mathbf{2}$ do not form mononuclear tridentate complexes due to the restriction of motion of the a-carbon adjacent to the amide nitrogen, preventing the carboxylate oxygen from binding to the same rhenium centre as the amine and amide carbonyl oxygen. In contrast, others have shown that using $\mathrm{L}=\mathrm{C}_{5} \mathrm{H}_{4} \mathrm{~N}-2$ $\mathrm{CH}_{2} \mathrm{NHCH}_{2} \mathrm{X}\left(\mathrm{X}=\mathrm{CO}_{2}^{-}, \mathrm{CH}_{2} \mathrm{~S}^{-}\right.$or 2-pyridyl), with an $\mathrm{sp}^{3}$-amine nitrogen instead of an $\mathrm{sp}^{2}$-amide nitrogen, produces the corresponding tridenatate $\mathrm{Re}(\mathrm{CO})_{3} \mathrm{~L}$ complex with two five-member rings that show no ring strain. ${ }^{[27-29]}$ Despite the presence of halide ions in the reaction solution, the carboxylate ion forms a bridge to the second rhenium center, providing charge balance for the $\operatorname{Re}(\mathrm{I})$ ion. The observed modest yields in forming $\mathbf{1}$ and $\mathbf{2}$ are likely due to other reaction pathways available to the distal carboxylate, leading to byproducts that were not isolable. 
Each compound forms a nearly rectangular shape as traced by the two rhenium centers and two a-carbons on the amino acids (see Figures 3 and 4). Compound 1 in particular comes close to a true rectangular shape. The $\operatorname{Re}(1)-\mathrm{C}(6)$ separation is $\sim 4.91 \AA$, while $\operatorname{Re}(1)-\mathrm{C}(6 \mathrm{~A})$ is $\sim 4.45 \AA$. The $\mathrm{C}(6)-\operatorname{Re}(1)-\mathrm{C}(6 \mathrm{~A})$ angle is $\sim 88^{\circ}$, while $\operatorname{Re}(1)-\mathrm{C}(6)-\operatorname{Re}(1 \mathrm{~A})$ is $\sim 92^{\circ}$. $\mathrm{C}(6 \mathrm{~A})$ lies only $\sim 2^{\circ}$ off the plane created by $\operatorname{Re}(1), \mathrm{C}(6)$ and $\operatorname{Re}(1 \mathrm{~A})$. Compound 2 adopts a butterfly shape. The $\operatorname{Re}(1)-\mathrm{C}(6)$ separation is $\sim 4.90 \AA$, while $\operatorname{Re}(1)-\mathrm{C}(6 \mathrm{~A})$ is $\sim 4.44 \AA$. The $\mathrm{C}(6)-\operatorname{Re}(1)-\mathrm{C}(6 \mathrm{~A})$ angle is $\sim 89^{\circ}$, while $\operatorname{Re}(1)-\mathrm{C}(6)-\operatorname{Re}(1 \mathrm{~A})$ is $\sim 88^{\circ}$. $\mathrm{C}(6 \mathrm{~A})$ lies $\sim 28^{\circ}$ off the plane created by $\operatorname{Re}(1), \mathrm{C}(6)$ and $\operatorname{Re}(1 \mathrm{~A})$.

The steric interaction in $\mathbf{2}$ of the methyl groups with contiguous atoms likely prevents formation of a more ideal rectangular shape. More importantly, it also prevents formation of the second diastereomer because of the steric interaction that would result between $\mathrm{O}(4)$ and $\mathrm{C}(7)$, the amide carbonyl oxygen and side-chain methyl group. Both available stereoisomers and a more symmetric shape are observed for $\mathbf{1}$ because this steric interaction is absent. The steric constraints that limit dimer formation are likely the reason that other dipeptides (e.g. Ala-Gly-OH, Ala-Ala-OH, His-Gly-OH and Gly-His-OH) did not form isolable products.

Compound $\mathbf{1}$ crystallizes in the $C 2 / c$ space group with a DMSO solvent molecule; each enantiomer appears in the unit cell. As Ala-Gly-OH is chiral, $\mathbf{2}$ is also chiral and crystallizes in the chiral space group $C 222 / 1$. While $C_{2}$ symmetry is a common feature of multinuclear $\operatorname{Re}(\mathrm{CO})_{3}$ complexes with amino acid derivatized ligands, it is worth noting that trimeric structures with proline or dimethylglycine have also been reported. The former compound has a three-fold axis while the latter lacks a symmetry element. ${ }^{[30]}$

The simple infrared metal carbonyl stretching pattern observed for $\mathbf{1}$ and $\mathbf{2}$ is consistent with each compound having identical pseudo- $C_{3 V}$ metal centers. The NMR spectra of these compounds confirm their structural features. The ${ }^{1} \mathrm{H}$ NMR spectrum of each compound is more complicated than the spectrum of the parent ligand due to diasterotopic methylene hydrogen atoms formed with the creation of the ring structure. The ${ }^{13} \mathrm{C}$ NMR spectrum of each compound corroborates their $C_{2}$ symmetry: one signal is reported for each pair of symmetry-related carbons. The ${ }^{1} \mathrm{H}$ and ${ }^{13} \mathrm{C}$ NMR spectra of $\mathbf{2}$ each verify that this compound consists of a single diastereomer.

\section{Conclusions}

Compounds $\mathbf{1}$ and $\mathbf{2}$ are rare examples of organometallic dipeptide compounds, and each shows a $C_{Z^{-}}$-symmetric dimer structure. Compound $\mathbf{1}$ has chirality enforced on it due to the chiral metal center; both enantiomers were observed. Compound $\mathbf{2}$ was prepared as a single diastereomer as steric interactions control the geometry observed in the product. While there are numerous examples of coordination compounds with peptide ligands, the His-His-OH compound in Scheme $1^{[21]}$ and the compounds reported here are the only examples of structurally elucidated metal carbonyl complexes with unmodified peptide ligands. Given the variety of chemistry already observed and the potential of ${ }^{188} \operatorname{Re}(\mathrm{CO})_{3}$ bioconjugates in medicinal applications, we are pursuing further studies in this area.

\section{Experimental Section}

X-ray intensity data were measured at $100 \mathrm{~K}$ (Bruker KYRO-FLEX) on a Bruker SMART APEX CCD-based X-ray diffractometer system equipped with a Mo-target X-ray tube $(\lambda=$ $0.71073 \AA$ A) operated at $2000 \mathrm{~W}$ power. The crystals were mounted on a cryoloop using Paratone N-Exxon oil and placed under a stream of nitrogen at $100 \mathrm{~K}$. The detector was placed at a distance of $5.009 \mathrm{~cm}$ from the crystals. The data were corrected for absorption with the SADABS program. The structures were refined using the Bruker SHELXTL 
Software Package (Version 6.1), and were solved using direct methods until the final anisotropic full-matrix, least squares refinement of $F^{2}$ converged.

Two methods were effective in preparing these compounds. Method A: $\operatorname{Re}(\mathrm{CO})_{5} \mathrm{Cl}(0.150 \mathrm{~g}$, $4.15 \times 10^{-4} \mathrm{~mol}$ ) and one equivalent of the appropriate dipeptide were added to a roundbottom flask containing $9 \mathrm{~mL}$ of methanol and $1 \mathrm{~mL}$ of deionized water. The mixture was refluxed for 4 hours, producing a clear solution. Solvent was removed yielding a lightyellow oily liquid. $2 \mathrm{~mL}$ of cold water was added and stirred. The water was removed by filtration and the off-white solid was dried. Method B: $\left[\operatorname{Re}(\mathrm{CO})_{3}\left(\mathrm{H}_{2} \mathrm{O}\right)_{3}\right] \mathrm{Br}(0.150 \mathrm{~g}, 3.71 \times$ $10^{-4} \mathrm{~mol}$ ) and one equivalent of the appropriate dipeptide were added to a round-bottom flask containing $10 \mathrm{~mL}$ of deionized water. The mixture was refluxed for one hour and the compound was isolated as described above.

$\left[\mathrm{Re}(\mathrm{CO})_{3}(\mathrm{Gly}-\mathrm{Gly}-\mathrm{O})^{-}\right]_{2}$ 1: $14 \%$ yield. IR: 3340 (w), 3252, (w), 2017 (s), 1853 (vs), 1627 $(\mathrm{m}), 1592(\mathrm{~m}), 1567(\mathrm{~m}) \mathrm{cm}^{-1}$. Anal. Calc. for $\mathrm{C}_{14} \mathrm{H}_{14} \mathrm{~N}_{4} \mathrm{O}_{12} \mathrm{Re}_{2} \cdot\left(\mathrm{CH}_{3} \mathrm{OH}\right): \mathrm{C}, 21.58 ; \mathrm{H}$, 2.17; N, 6.71. Found: C, 21.67; H, 2.09; N, 6.71. ${ }^{1} \mathrm{H}$ NMR ( $d_{6}$-DMSO): $\delta 9.39$ (dd, J = 9.6, $2.8 \mathrm{~Hz}, 1 \mathrm{H}, \mathrm{CON} H), 5.31\left(\mathrm{dt}, \mathrm{J}=10.8,6.4 \mathrm{~Hz}, 1 \mathrm{H}, \mathrm{N} H_{2}\right), 4.41(\mathrm{dt}, \mathrm{J}=10.8,6.4 \mathrm{~Hz}, 1 \mathrm{H}$, $\left.\mathrm{NH}_{2}\right), 4.00\left(\mathrm{dd}, \mathrm{J}=16.8,9.6 \mathrm{~Hz}, 1 \mathrm{H}, \mathrm{CH}_{2}\right), 3.66\left(\mathrm{t}, \mathrm{J}=6.4,6.4 \mathrm{~Hz}, 2 \mathrm{H}, \mathrm{CH}_{2}\right), 3.39(\mathrm{dd}, \mathrm{J}=$ 16.8, $\left.3.2 \mathrm{~Hz}, 1 \mathrm{H}, \mathrm{C} H_{2}\right)$. 13C NMR ( $d_{6}$-DMSO): $\delta$ 198.2, 197.5, 197.3, 180.9, 169.6, 43.9, 42.8 .

$\left[\operatorname{Re}(\mathrm{CO})_{3}\left(\mathrm{Gly}^{-} \mathrm{Ala}^{-} \mathrm{O}^{-}\right)\right]_{2}$ 2: $20 \%$ yield. IR: 3336 (w), 3252, (w), 2022 (s), 1908 (s), 1856 (s), 1577 (s) $\mathrm{cm}^{-1}$. Anal. Calc. for $\mathrm{C}_{16} \mathrm{H}_{14} \mathrm{~N}_{4} \mathrm{O}_{12} \mathrm{Re}_{2} \cdot 6 \mathrm{H}_{2} \mathrm{O}: \mathrm{C}, 20.46 ; \mathrm{H}, 3.22 ; \mathrm{N}, 5.96$. Found: C, 20.41; H, 2.94; N, 5.99. ${ }^{1} \mathrm{H}$ NMR ( $d_{6}$-DMSO): $\delta 9.33$ (d, J = $\left.8.8 \mathrm{~Hz}, 1 \mathrm{H}, \mathrm{CONH}\right), 5.34$ (m, $\left.1 \mathrm{H}, \mathrm{NH}_{2}\right), 4.39\left(\mathrm{~m}, 1 \mathrm{H}, \mathrm{NH}_{2}\right), 4.18\left(\mathrm{~m}, 1 \mathrm{H}, \mathrm{CHCH}_{3}\right), 3.64-3.25$ (br m, $2 \mathrm{H}, \mathrm{NH}_{2} \mathrm{CH}_{2}$ ), $1.24\left(\mathrm{~d}, \mathrm{~J}=7.2 \mathrm{~Hz}, 3 \mathrm{H}, \mathrm{CH}_{3}\right) .{ }^{13} \mathrm{C}$ NMR $\left(d_{6}\right.$-DMSO): $\delta 198.2,197.6,197.4,179.9,172.5$, $49.5,43.9,18.5$.

\section{Acknowledgments}

RSH would like to thank the Research Corporation (CC6663/6616) and the Petroleum Research Fund (51085-UR3) for financial support of this research. CJZ acknowledges the National Institutes of Health (R15 GM083322) for funds used in this work. KLK thanks the Beckman Scholars Fund, and CL thanks The Alumni/Parents Summer Research Scholarship for financial support.

\section{References}

1. Herrick, RS. New Developments in Organometallic Research. Cato, MA., editor. Nova Science Publishers, Inc; New York: 2006. p. 117-149.

2. Schibli R, Schubiger PA. Eur J Nucl Med Mol Imaging. 2002; 29:1529-1542. [PubMed: 12397472]

3. Amato I. Nuclear Medicine's Conundrum. Chem and Engr News. Sep 7; 2009 87(36):58-64.

4. Alberto R, Ortner K, Wheatley N, Schibli R, Schubiger AP. J Am Chem Soc. 2001; 123:3135-3136. [PubMed: 11457025]

5. Schibli R, Schwarzbach R, Alberto R, Ortner K, Schmalle H, Dumas C, Egli A, Schubiger PA. Bioconjugate Chem. 2002; 13:750-756.

6. Kozminski P, Gniazdowska E, Fuks L, Kowalska S. Appl Radiat Isot. 2011; 69:436-442. [PubMed: 21129987]

7. Fuks L, Gniazdowska E, Kozminski P, Lyczko M, Mieczkowski J, Narbutt J. Appl Radiat Isot. 2009; 68:90-95. [PubMed: 19766012]

8. Alberto, R. Bioinorganic Medicinal Chemistry. Alessio, E., editor. Wiley-VCH; Weinheim: 2011. p. 253-282.

9. Ruggi, A.; Reinhoudt, DN.; Velders, AH. Bioinorganic Medicinal Chemistry. Alessio, E., editor. Wiley-VCH; Weinheim: 2011. p. 383-406.

10. Lo KKW, Louie MW, Zhang KY. Coord Chem Rev. 2010; 254:2603-2622. 
11. Balasingham RG, Coogan MP, Thorp-Greenwood FL. Dalton Trans. 2011; 40:11663-11674. [PubMed: 21897946]

12. Herrick RS, Ziegler CJ, Çetin A, Franklin BR. Eur J Inorg Chem. 2007:1632-1634.

13. Franklin BR, Herrick RS, Ziegler CJ, Çetin A, Barone N, Condon LR. Inorg Chem. 2008; 47:5902-5909. [PubMed: 18510286]

14. Herrick RS, Ziegler CJ, Sripothongnak S, Barone N, Costa R, Cupelo W, Gambella A. J Organomet Chem. 2009; 694:3929-3934.

15. Herrick RS, Wrona I, McMicken N, Jones G, Ziegler CJ, Shaw J. J Organomet Chem. 2004; 689:4848-4855.

16. Costa R, Barone N, Gorczycka C, Powers EF, Cupelo W, Lopez J, Herrick RS, Ziegler CJ. J Organomet Chem. 2009; 694:2163-2170.

17. Herrick RS, Ziegler CJ, Jameson DL, Aquina C, Çetin A, Franklin BR, Condon LR, Barone N, Lopez J. Dalton Trans. 2008:3605-3609. [PubMed: 18594710]

18. Binkley SL, Barone NV, Underwood AC, Milsted A, Franklin BR, Herrick RS, Ziegler CJ. J Inorg Biochem. 2010; 104:632-638. [PubMed: 20362340]

19. Herrick RS, Brunker TJ, Maus C, Crandall K, Çetin A, Ziegler CJ. Chem Commun. 2006:43304331.

20. Liu S. Chem Soc Rev. 2004; 33:445-461. [PubMed: 15354226]

21. Herrick RS, Ziegler CJ, Gambella A. Eur J Inorg Chem. 2010:3905-3908.

22. Qayyum H, Herrick RS, Ziegler CJ. Dalton Trans. 2011; 40:7442-7445. [PubMed: 21691650]

23. Binkley SL, Leeper TC, Rowlett RS, Herrick RS, Ziegler CJ. Metallomics. 2011; 3:909-916. [PubMed: 21805003]

24. Binkley SL, Ziegler CJ, Herrick RS, Rowlett RS. Chem Commun. 2010; 46:1203-1205.

25. Herrick RS, Ziegler CJ, Lopez J, Barone NV, Gambella A, Masi C. J Organomet Chem. 2012; 700:160-165.

26. All crystallographic data was collected at $100 \mathrm{~K}$ (Bruker KRYOFLEX) with a Bruker SMART APEX CCD-based X-ray diffractometer (Mo-K $\mathrm{K}_{\alpha}$ radiation, $\lambda=0.71073 \AA$ ). The structures were refined by using the Bruker SHELXTL Software Package (Version 6.10) and were solved until the final anisotropic full-matrix, least-squares refinement of $F^{2}$ converged. Crystallographic summary for 1: $\mathrm{C}_{18} \mathrm{H}_{26} \mathrm{~N}_{4} \mathrm{O}_{14} \mathrm{Re}_{2} \mathrm{~S}_{2} ; M_{r}=958.95$; colorless block; $0.34 \times 0.29 \times 0.18 \mathrm{~mm}$; monoclinic, $C 2 / c, Z=8 ; a=13.596(3) \AA, \quad b=9.696(2) \AA, c=25.262(8) \AA, \beta=101.952(5)^{\circ} ; V=3258.0(18)$ $\AA^{3}, \rho=1.955 \mathrm{Mg} \mathrm{m}^{-3}$. A total of 11300 reflections were collected (3347 independent reflections). $F(000)=1824, R 1=0.0734, w R 2=0.1732$ [for $\left.3158 \mathrm{I}_{\mathrm{O}}, \mathrm{I}_{\mathrm{O}}>2 \sigma\left(\mathrm{I}_{\mathrm{O}}\right)\right]$. Crystallographic summary for 2: $\mathrm{C}_{16} \mathrm{H}_{18} \mathrm{~N}_{4} \mathrm{O}_{12} \mathrm{Re}_{2} ; M_{r}=830.74$; colorless block; $0.36 \times 0.32 \times 0.30 \mathrm{~mm}$; orthorhombic, $C 222(1), Z=4 ; a=9.9665(11) \AA, b=15.1909(17) \AA, c=19.094(16) ; V=2890.8(6) \AA^{3}, \rho=$ $1.904 \mathrm{Mg} \mathrm{m}^{-3}$. A total of 11277 reflections were collected (2959 independent reflections). $F(000)$ $=1552, R 1=0.0208, w R 2=0.0519$ [for $2933 \mathrm{I}_{\mathrm{o}}, \mathrm{I}_{\mathrm{O}}>2 \sigma\left(\mathrm{I}_{\mathrm{O}}\right)$ ]. CCDC $910881-910882$ contain the supplementary crystallographic data for $\mathbf{1}$ and $\mathbf{2}$. These data can be obtained free of charge from The Cambridge Crystallographic Data Centre via www.ccdc.cam.ac.uk/data_request/cif.

27. Mundwiler S, Candreia L, Haefliger P, Ortner K, Alberto R. Bioconjugate Chem. 2004; 15:195202.

28. Kramer DJ, Davison A, Davis WM, Jones AG. Inorg Chem. 2002; 41:6181-6183. [PubMed: 12444754]

29. Banerjee SR, Levadala MK, Lazarova N, Wei L, Valliant JF, Stephenson KA, Babich JW, Maresca KP, Zubieta J. Inorg Chem. 2002; 41:6417-6425. [PubMed: 12444786]

30. Zobi F, Spingler B, Alberto R. ChemBioChem. 2005; 6:1397-1405. [PubMed: 15959921] 


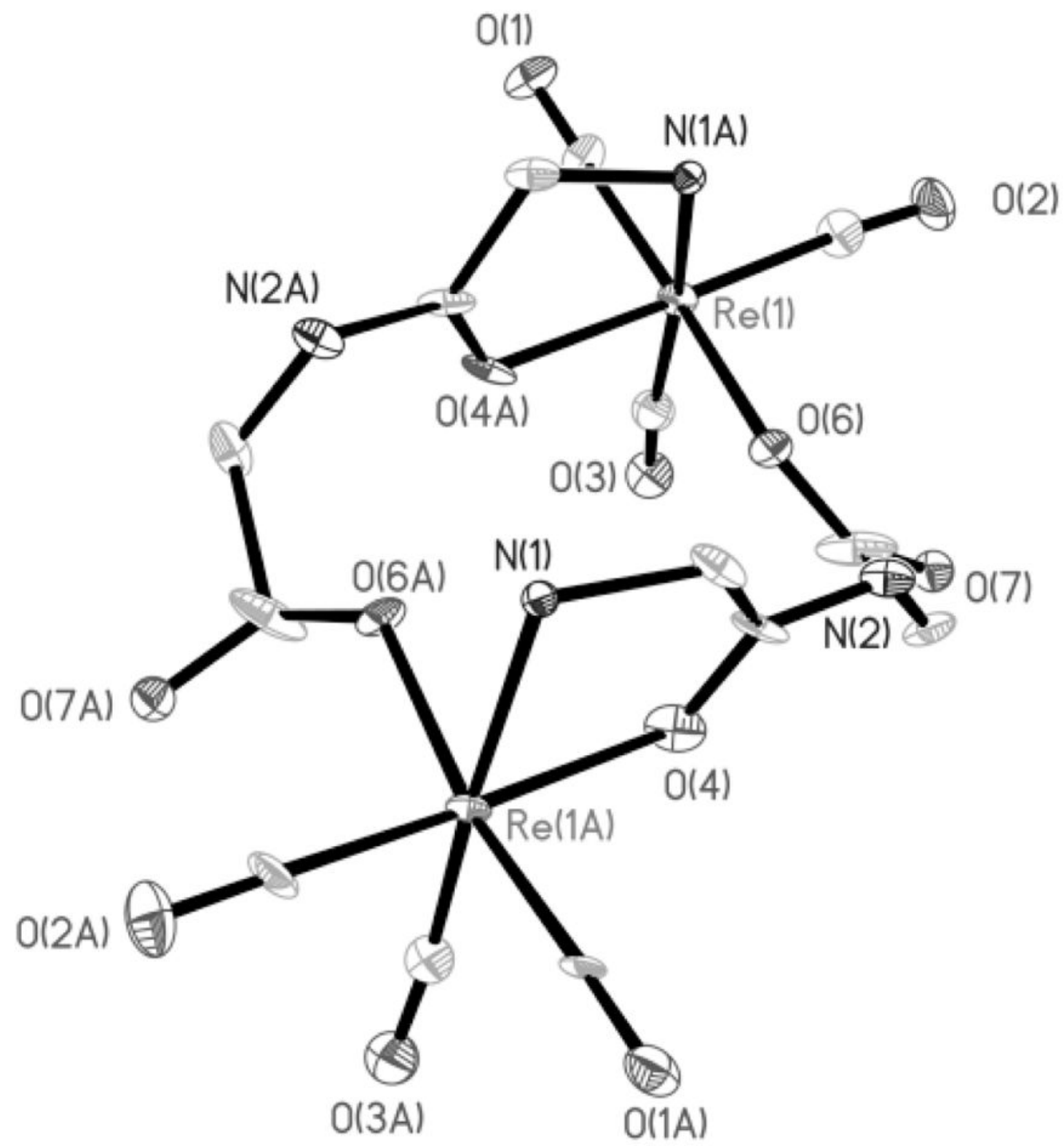

Figure 1.

Structure of 1 with 35\% thermal ellipsoids. Solvent DMSO and hydrogen atoms have been omitted for clarity. 


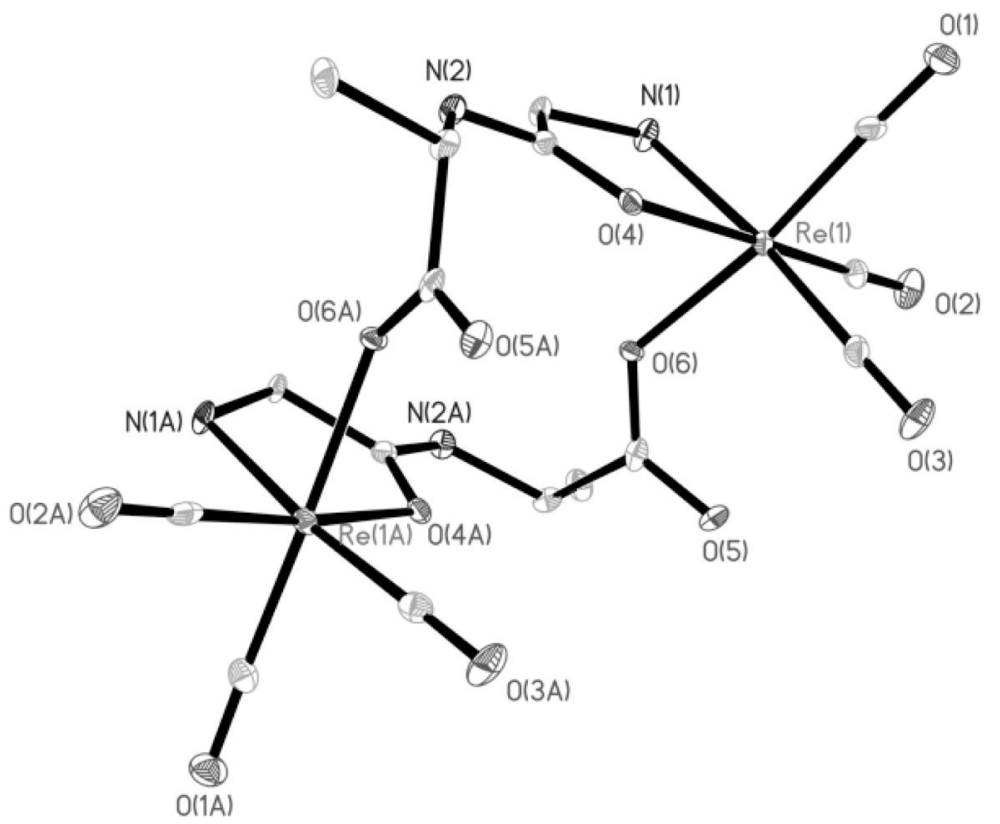

Figure 2.

Structure of $\mathbf{2}$ with 35\% thermal ellipsoids. Hydrogen atoms have been omitted for clarity. 


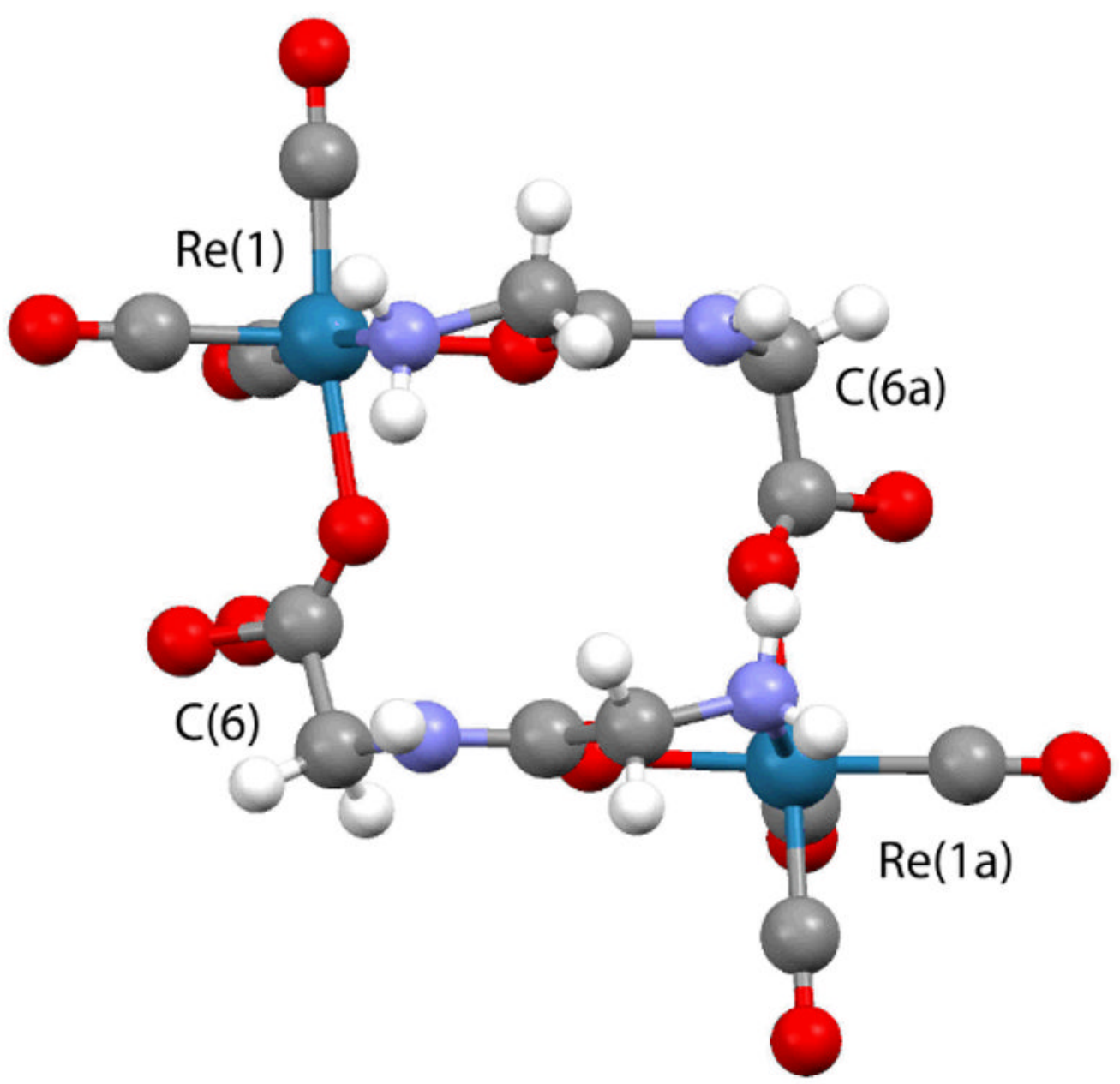

Figure 3.

Compound 1 viewed from above to highlight its rectangular shape. 


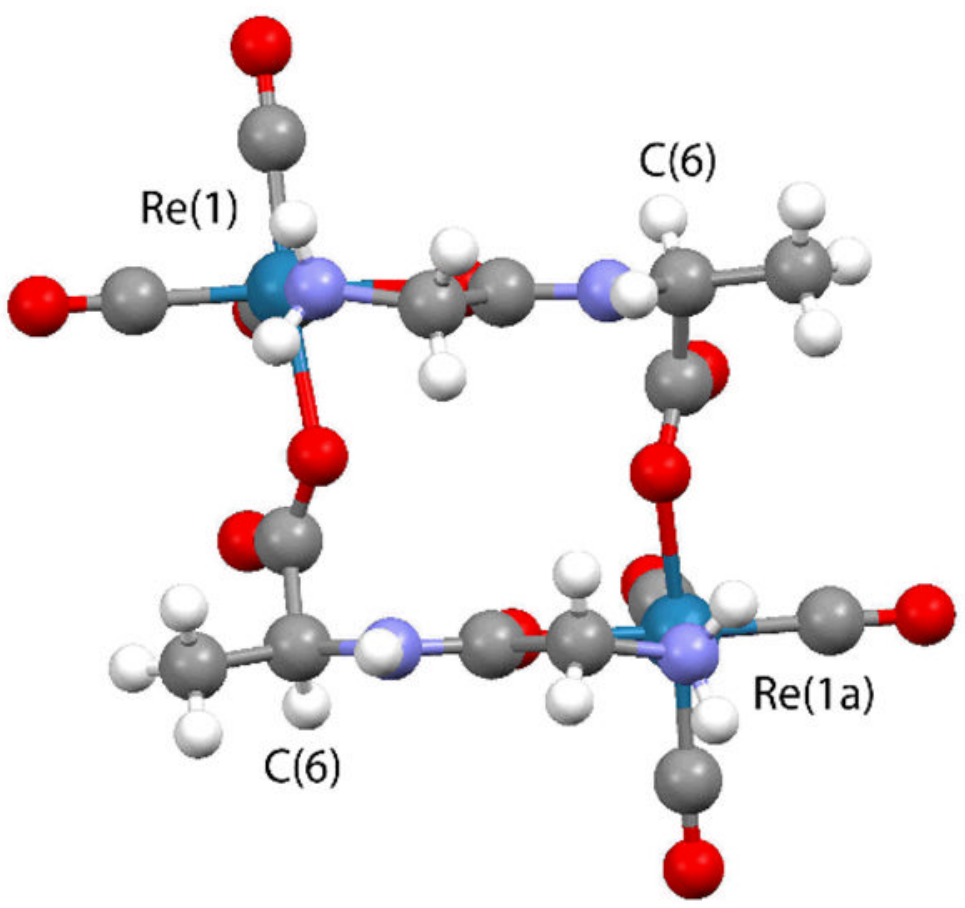

Figure 4.

Compound 2 viewed from above to highlight its rectangular shape. 


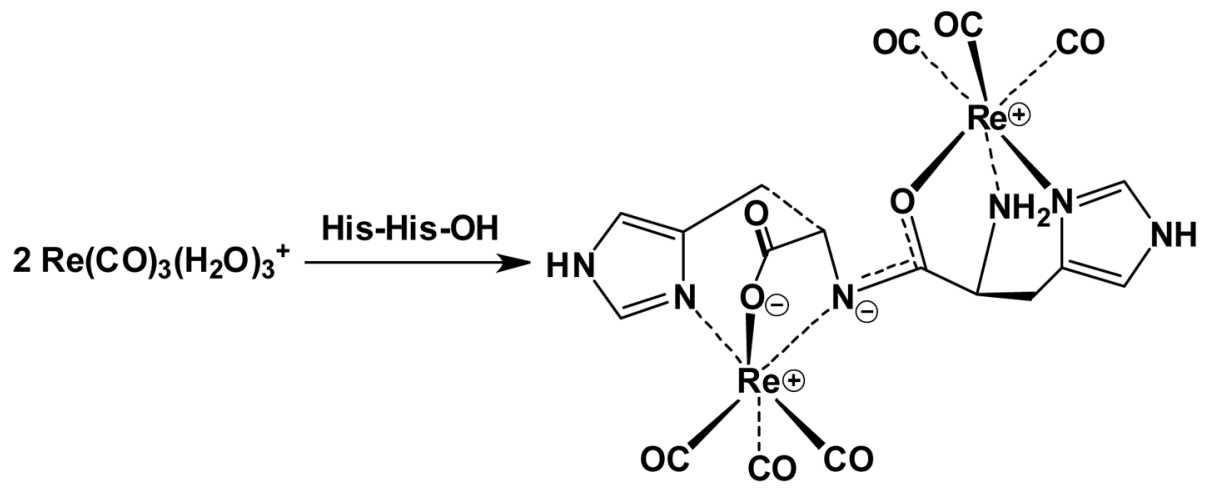

Scheme 1.

Preparation and connectivity of the compound formed by reaction of $\operatorname{Re}(\mathrm{CO})_{3}{ }^{+}$and His-His$\mathrm{OH}$. 


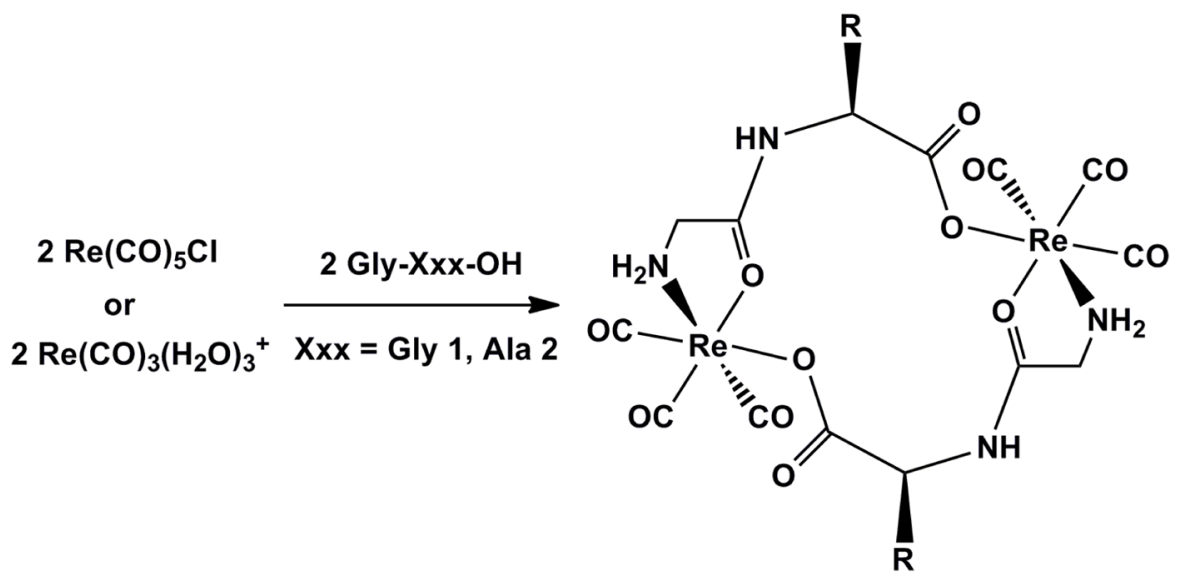

Scheme 2.

General reaction scheme for preparation of $\mathbf{1}$ and $\mathbf{2}$. 